\title{
GURU PAK SEBAGAI FASILITATOR DALAM MENGATASI MASALAH REMAJA USIA 13-14 TAHUN
}

\author{
Fantesia Salama \\ Sekolah Tinggi Agama Kristen Terpadu PESAT Salatiga \\ Email: salamafantesia@ gmail.com
}

\begin{abstract}
Abstrack
Adolescence is a period where there is a transition from childhood to adulthood, which is entering a period of transition, everything even changes occur in adolescence. The search for identity occurs in adolescence, adolescents also face various problems, both problems in the family, social and school environment. This problem really affects teenagers. In this case, how PAK teachers can act as facilitators for teenagers can help, assist and encourage them to be able to overcome the problems they face. In this writing, using library research methods or literature studies. A library that limits its activities to only library collection materials without the need for field research. The results of this literature research, namely how teachers can act as facilitators to help teenagers in dealing with every problem and encourage teens how to overcome the problems they face.

Keywords: Teacher, facilitator, PAK, Youth
\end{abstract}

Abstrak
Remaja adalah masa dimana terjadi peralihan dari masa anak-anak kepada masa dewasa, Remaja adalah masa dimana terjadi peralihan dari masa anak-anak kepada masa dewasa,
memasuki masa peralihan, segala hal bahkan perubahan terjadi di masa remaja. Pencarian jati diri terjadi di masa remaja, remaja juga menghadapi berbagai masalah, baik masalah di lingkungan keluarga, pergaulan, dan sekolah. Masalah tersebut sangat mempengaruhi diri remaja. Dalam hal ini bagaimana Guru PAK bisa berperan sebagai fasilitator untuk anak remaja dapat menolong, membantu dan mendorong mereka untuk dapat mengatasi masalah-masalah yang di hadapinya. Dalam penulisan ini, menggunakan metode penelitian pustaka atau studi literatur. Kepustakaan yang membatasi kegiatannya hanya pada bahan-bahan koleksi perpustakaan saja tanpa memerlukan riset lapangan. Hasil dari penelitian kepustakaan ini, yaitu bagaimana Guru dapat berperan sebagai fasilitator untuk menolong para remaja dalam menghadapi setiap masalahnya dan mendorong remaja bagaimana mengatasi masalah yang di hadapinya .

Kata kunci: Guru, fasilitator, PAK, Remaja 


\section{Pendahuluan}

Guru sebagai pendidik memiliki peran penting didalam membentuk anak menjadi pribadi yang akan menuju pada tahap dewasa. Guru sebagai manusia yang menempatkan posisi dan memengang peran penting dalam pendidikan. ${ }^{1}$. Untuk itu peran guru dalam menolong peserta didik sangat besar sekali, karena guru adalah orangtua kedua bagi anak ketika anak itu berada di sekolah, sehingga demikian guru bertanggungjawab besar dalam menolong anak remaja, sehingga setiap hal-hal yang dihadapi oleh remaja tersebut guru dapat membantu dan menolong mereka.

Di dalam Pendidikan Agama Kristen tidak hanya di berikan oleh gereja dalam lingkungan tertentu, tetapi di Sekolah umum juga ada yang namanya pendidikan agama Kristen, karena agama dan pendidikan tidak dapat dipisahkan. Karena Pendidikan agama sangat memperkuat iman dan karakter dari anak didik. ${ }^{2}$ Robert W. Pazmino mengungkapkan bahwa pendidikan agama Kristen merupakan :"usaha bersahaja dan sistematis, ditopang oleh upaya rohani dan manusiawi untuk mentrasmisikan

\footnotetext{
${ }^{1}$ Sriyati Sriyati and Esen Hon Nakamnanu, "Peran
} Guru Dalam Menerapkan Pendidikan Agama Kristen Untuk Menumbuhkan Iman Kristen Anak Sejak Dini," SHAMAYIM: Jurnal Teologi dan Pendidikan pengetahuan, nilai-nilai, sikap-sikap, keterampilan-keterampilan dan tingkah laku yang konsisten dengan iman Kristen, dalam mengupayakan perubahan, pembaharuan, dan reforasi pribadi-pribadi, kelompok bahkan struktur oleh kuasa Roh Kudus sehingga peserta didik hidup sesuai dengan kehendak Allah sebagaimana dinyatakan oleh Alkitab, terutama dalam Yesus Kristus. ${ }^{3}$

Berdasarkan yang ada pemahaman di atas, maka dapat disimpulkan bahwa pendidikan Kristen merupakan suatu kegiatan rohani yang melalui hal itu dapat memberikan pengetahuan dengan nilai-nilai yang dapat menolong dalam membentuk sikap seseorang.

Di sekolah Guuru PAK didalam melaksanakan tugasnya tidak saja berorientasi pada kognitif saja. Namun dapat membentuk kepribadian peserta didik (karakternya) dan juga iman kepercayaannya. Artinya pada pembelajaran PAK di sekolah harus bisa mengatasi permasalahn siswa dan melalui itu juga bagaimana guru PAK dapat menolong siswa dalam meningkatkan

Kristiani 1 , no. 1 (January 19, 2021): hal 15 , http://www.sttybmanado.ac.id/ejournal/index.php/shamayim/article/view/2.

${ }^{2}$ Ibid., hal 16.

${ }^{3}$ Ibid. 
spiritualitas siswa ini menjadi tugas dan tanggungjawab guru PAK. Oleh karena itu, untuk mencapai keberhasilan proses pembelajaran PAK sangatlah penting ditentukan dari bagaimana guru PAK tersebut mengajar. ${ }^{4}$ Dalam hal ini, salah satu indikator yang diharapkan dari guru PAK adalah mampu mengembangkan model dalam kegiatan belajar mengajar khususnya dalam pembelajaran PAK agar lebih menarik dan membuat siswa lebih aktif di dalama pembelajaran (Boiliu \& sinaga, 2021).

\section{Dengan demikian guru PAK bertugas \\ dan bertanggungjawab di dalam} pembelajaran untuk bisa berperan sebagai fasilitator dalam membantu dan menolong setiap permasalahan yang dihadapi siswa terutama yang mulai masuk pada usia remaja yang dimana pada fase perkembangannya banyak hal yang di hadapinya untuk itu, guru PAK bisa hadir untuk siswa melalui sekolah, dalam mengatasi setiap permasalah yang di alami remaja tersebut.

Karena pada Masa remaja ini, merupakan masa transisi dari masa kanakkanak menuju tingkat kematangan untuk persiapan mencapai kedewasaan. Berarti

${ }^{4}$ C S Niwalmars and Fredik Melkias Boiliu, "Efektivitas Pembelajaran Pendidikan Agama Kristen Dalam Menangani Peserta Didik Yang Bermasalah Di kemajuan perkembangan yang dicapai di dalam masa remaja merupakan bekal keberhasilan yang akan ada di masa dewasa. Melalui suatu proses transisi, masa remaja di tandai dengan berbagai perubahan dalam berbagai aspek baik itu fisik, mental, intelektual, dan sosial. Perubahan-perubahan yang terjadi pada masa ini demikian besarnya sehingga menimbulkan "kejutan" bagi remaja itu sendiri dan bagi lingkungannya. Jika perkembangan itu diibaratkan seperti laut maka masa remaja merupakan lautan dengan gelombang yang tertinggi. Sebutan masa strom and stress pada masa remaja karena kuatnya gelombang dan guncangkan yang terjadi di dalamnya. Ada juga yang menyebutkan masa remaja sebagai masa kelahiran kedua karena dalam masa itu remaja akan menunjukkan jati dirinya sehingga perubahan mulai banyak terjadi pada masa ini. ${ }^{5}$

Keberadaa Remaja di dalam gereja maupun di sekolah-sekolah dalam konteks masyarakat Indonesia adalah suatu bidang yang strategis, tetapi juga sangat menantang karena remaja berada dalam fase keluarga yang sangat penting untuk masa depannya.

Sekolah," EDUKATIF: JURNAL ILMU PENDIDIKAN 3, no. 3 (2021): 1038-1049.

${ }^{5}$ Wulandari S and 2019, Perilaku Remaja (semarang, n.d.), hal 4. 
Karena masa remaja adalah masa transisi dengan berbagai gejolak yang muncul. ${ }^{6}$ Untuk itu dalam masa-masa usia remaja ini yang dimana ia mencari jati dirinya. Untuk itu remaja juga mengalami yang namanya masalah, dan ketika remaja tersebut berada di lingkungan sekolah yang dapat menolongnya dan membantu dalam mendorongnya bagaimana menghadapi masalahnya tersebut, itu adalah guru. guru dapat berperan penting sebagai fasilitator untuk anak remaja dalam menghadapi masalah-masalahnya di lingkungan di mana anak remaja tersebut berada. bagaimana Sebagai Guru PAK yang menerapkan setiap nilai-nilai kekristenan dapat juga menolong dan membantu setiap remaja dalam menghadapi masalah-masalah yang di alaminya tersebut, bukan saja memberikan materi tetapi Guru PAK juga bisa bertugas dalam menanggulangi masalahmasalah remaja yang dihadapinya.

\section{Metode Penelitian}

Berdasarkan latar belakang yang sudah di paparkan di atas, tulisan ini menggunakan metode penelitian pustaka atau studi literatur. Di dalam buku metode penelitian kepustakaan library Research oleh

${ }^{6}$ Daniel Nuhamara, PAK REMAJA (bandung, 2008), hal 3.

${ }^{7}$ Amirr Hamzah, Metode Penelitian Kepustakaan (Library Research) (Malang, 2020), hal 7.
Dr. Amir Hamzah, M.A. mengatakan bahwa penelitian kepustakaan adalah cara kerja ilmiah yang tergolong dalam jenis penelittian kualitatif. Dalam penelitian ini riset pustakanya membatasi kegiataanya yaitu, pada bahan-bahan koleksi perpustakaan saja tanpa memerlukan riset dari lapangan. ${ }^{7}$

\section{Pembahasan dan Hasil}

\section{Peran Guru PAK sebagai fasilitator}

Guru tidak mengambil peserta didik melalui cerita, ceramah atau penjelasan. Namun, ia memandang anak didik sebagai pribadi yang bertanggungjawab, mampu mengolah sumber-sumber belajar sehingga mereka melakukan kegiatan belajar berdasarkan petunjuk yang tepat, sebagai fasilitator, guru pun menyediakan waktunya untuk bisa berkonsultasi secara pribadi ataupun kelompok kecil dengan peserta didik, baik didalam maupun di ruangan kelas. ${ }^{8}$ Dengan begitu, guru bisa mengatasi kesulitan dalam masalah-masalah yang di hadapi Remaja.

PAK tidak terlepas dari sang guru agung yaitu Tuhan Yesus Kristus. Yesus

\footnotetext{
${ }^{8}$ B.s. Sidjabat, Mengajar Secara Profesional (bandung, n.d.), hal 111.
} 
yang sebagai penebus dan pembebas, adalah Guru Agung juga mengajar murid-muridnya dan cara Yesus mengajar sangatlah menarik.

Karena Yesus bukan saja mengajarkan firman namun Tuhan Yesus juga mengajarkan bahkan menolong mereka dalam menghadapi masalah yang di hadapi murid-murid-Nya. Yesus adalah guru yang luarbiasa, setiap pengajaran-Nya Yesus adalah pengajar yang mulia. Sebagai pendidik dalam menolong setiap anak-anak yang ada, bisa dilihat dari keteladanan sang guru agung yaitu Tuhan Yesus sendiri dalam mengajar Yesus memiliki kedekatan dengan murid-murid-Nya, sehingga Yesus sendiri sangat mengenal karakter dari muridmuridnya. ${ }^{9}$ Untuk itu Sebagai guru PAK dapat melihat dari keteladanan Tuhan Yesus yang bisa membangun kedekatan dengan setiap murid-muridnya, demikian juga Guru PAK yang sebagai fasilitator bagaimana fasilitator itu berperan dalam menolong setiap anak remaja, dalam membangun kedekatan kepada setiap mereka .Untuk itu guru juga bisa mengenal bagaimana setiap karakter peserta didiknya. Karena Guru PAK harus memiliki tujuan yang jelas dalam mengajar serta memiliki hubungan yang

${ }^{9}$ Nainggolan John M, Menjadi Guru Agama Kristen(Suatu Upaya Peningkatan Mutu Dan Kualitas Profesi Keguruan) (bandung, 2007), hal 19-20. dekat dengan murid-murid sehingga dapat mengenal karakter murid-muridnya dengan baik. $^{10}$

Menjadi Fasilitator bukan saja mahir di dalam mengajar dan melatih saja, tetapi juga menggunakan kemahirannya untuk menolong setiap anak-anak remaja yang ada. Fasilitator juga mampu memudahkan anak didiknya dalam mengambil keputusan, agar Remaja juga bisa belajar bagaimana cara dalam menyelesaikan setiap masalahmasalah yang di hadapinya. Sangat penting untuk di perhatikan oleh pendidik dalam PAK Remaja ini dengan perbedaan antar tingkat perkembangan tahap ke tiga dan ke empat. Perbedaan ini membawa dampak yang cukup mendasar bagi PAK remaja dalam jemaat maupun dalam pendidikan secara umum. Pelayan remaja dan pendidik dapat menjadi bagian yang vital dari proses itu dengan memberi kesempatan-kesempatan untuk membina dan menstimulasi pikiran mereka yang sedang berkembang. ${ }^{11}$

\section{Masalah-Masalah Yang Di Hadapi Remaja}

\footnotetext{
${ }^{10}$ Ibid., hal

25.

${ }^{11}$ Nuhamara, PAK REMAJA, hal 62.
} 
Dalam fase ini terjadi banyak perubahan dan mulai memasuki dalam mencapai pada puncaknya perubahan. tidak stabilnya emosi dalam banyak hal terdapat pada usia ini. Remaja yang mencari identitas diri dalam masa ini, juga statusnya belum jelas. Polapola hubungan sosial mulai berubah, menyerupai orang dewasa muda, remaja merasa berhak untuk membuat keputusan sendiri. Pada masa perkembangan ini, pencapaian kemandirian dan identitas sangat menonjol, pemikiran semakin logis, dan juga mulai terbentuk pada pemikiran yang ideallis dan semakin banyak waktu diluangkan di luar keluarga. ${ }^{12}$ Pada tahap usia remaja mempunyai tugas perkembangan yang harus dilalui remaja biasanya bertentangan dan pemberontakan adalah bagian alamiah dari kebutuhan para remaja untuk menjadi dewasa yang mandiri dan peka secara emosional. Remaja suka memberontak dan ideallis dan terkadang keteganganketegangan sering terjadi dengan menantang orangtua, guru dan orang-orang yang ada di sekitar mereka, segala hal-hal yang tidak baik di hadapi remaja yang minim kurangnya keterlibatan keluarga dan minimnya bimbingan dari orangtua terhadap remaja sehingga dapat menimbuulkan rasa tidak aman untuk remaja itu sendiri. Ada beberapa masalah yang mempengaruhi sebagian besar remaja, yang paling berisiko adalah remaja yang memiliki masalah lebih dari satu masalah . Lambat laun para peneliti menemukan bahwa perilaku bermasalah yang di alami di masa remaja saling berkaitan. Sebagai contoh, penyalahgunaan obat terlarang yang parah berkaitan dengan, putus sekolah, kenakalan, rendahnya nilai sekolah. Aktivitas seksual dini, berkaitan dengan penggunaan rokok, alkohol, dan obat-obat narkotika lainnya. Meskipun tidak semuanya sebagian anak-anak muda berisiko tinggi "melakukan semua hal tersebut". Faktor lain yang juga ikut mempengaruhi perilaku kenakalan pada remaja adalah konsep diri yang juga merupakan pandangan atau keyakinan diri terhadap keseluruhan dirinya, baik yang menyangkut kelebihan maupun kekurangan dirinya, sehingga hal ini mempunyai pengaruh yang besar terhadap keseluruhan perilaku yang di tampilkan. Konsep diri terbentuk dan berkembang berdasarkan pengalaman dan interprestasi dari lingkungan, penilaian orang lain, atribut dan tingkah laku dirinya. Masa remaja

\footnotetext{
${ }^{12}$ Amita Diananda, "Psikologi Remaja Dan Permasalahannya," ISTIGHNA: Jurnal Pendidikan dan Pemikiran Islam 1, no. 1 (2019): hal 118.
} 
merupakan saat dimana remaja mengalami kesadaran akan dirinya tentang bagaimana pendapat orang lain tentang dirinya. Pada masa tersebut kemampuan kognitif mulai berkembang, sehingga remaja tidak hanya mampu membentuk pengertian mengenai apa yang ada dalam pikirannya, namun remaja akan berusaha pula untuk mengetahui pikiran orang lain tentang dirinya. ${ }^{13}$ Untuk itu dalam hal ini sebagai Guru PAK harus dapat lagi melihat perkembangan setiap masalahmasalah yang dihadapinya sehingga Guru PAK yang juga berperan sebagai fasilitator mengetahui bagaimana menolong setiap remaja yang sesuai dengan masalah-masalah yang di hadapinya baik di lingkungan keluarga, sekolah, maupun pergaulannya karena tentu banyak masalah yang di hadapinya dengan demikian guru dan keluarga harus banyak berperan penting untuk dapat menolong dan mendorongnya melewati fase demi fase yang sesuai dengan tahap-tahapnya dan diri remaja itu sendiri.

\section{Implikasi Guru PAK Kepada Remaja}

Dalam menolong remaja guru dapat memperhatikan hal-hal seperti berikut Yang pertama, Sabar karena guru membutuhkan kesabaran yang sungguh-sungguh dalam menangani remaja namun juga dengan bersikap tegas, kedua disiplin, kedisiplinan sangatlah baik untuk di terapkan, tetapi tidak membuat remaja merasa untuk dikontrol/dipaksa oleh kita, namun kedisiplinan di buat dengan kesepakatan bersama, ketiga hal yang harus di perhatikan oleh seorang guru adalah jangan mempermainkan emosi remaja, karena pada usia remaja mereka sangat sensitif untuk itu guru harus dapat menjaga emosinya, keempat yakinkanlah kepada remaja bahwa iman, tidak tergantung pada perasaan, namun beryakinkan pada iman yang teguh, kelima memotivasi remaja pikiran remaja dengan proses belajar dapat menciptakan suasana yang bersahabat, dan juga melalui motivasi remaja di yakinkan bahwa mereka spesial, penting, dan berharga, yang keenam Perhatikan mereka yang mungkin ditolak Dalam kelompoknya, dan selalu ada yang tidak dapat cocok satu dengan yang lainnya, artinya ada remaja yang sungguh mengalami kesulitan untuk berteman dan memperoleh penerimaan dari orang lain. Alasan penolakan bisa saja bermacam-macam seperti penampilan, kepribadian,latar belakang,keluarga dan lainnya. Untuk itu tugas guru PAK adalah memperhatikan seandainya ada diantara remaja yang ditolak dan berusaha menolong mereka dan mencari

\footnotetext{
${ }^{13}$ Ibid., hal 128-130.
} 
tahu alasan mengapa di tolak serta bisa

memberika pertolongan yang tepat. ${ }^{14}$

\section{Kesimpulan}

Jadi sebagai Guru PAK yang berperan sebagai fasilitator dalam menolong remaja dapat memberikan lingkungan belajar yang nyaman di sekolah, sehingga dengan demikian guru bisa menolong apa saja masalah bahkan kesulitan yang di hadapi remaja dengan tidak menekan namun guru dapat membimbing bagaimana cara menghadapi masalah-masalah remaja tersebut

\section{Daftar pustaka}

B.s.Sidjabat. Mengajar Secara Profesional. bandung, 2017.

Diananda, Amita. "Psikologi Remaja Dan Permasalahannya.” ISTIGHNA: Jurnal Pendidikan dan Pemikiran Islam 1, no. 1 (2019): 116-133.

Hamzah, Amirr. Metode Penelitian Kepustakaan (Library Research).
Malang, 2020. John M, Nainggolan. Menjadi Guru Agama Kristen(Suatu Upaya Peningkatan Mutu Dan Kualitas Profesi Keguruan). bandung, 2007.

Niwalmars, C S, and Fredik Melkias Boiliu. "Efektivitas Pembelajaran Pendidikan Agama Kristen Dalam Menangani Peserta Didik Yang Bermasalah Di Sekolah.” EDUKATIF: JURNAL ILMU PENDIDIKAN 3, no. 3 (2021): 1038 1049.

Nuhamara, Daniel. PAK REMAJA. bandung, 2008.

S, Wulandari, and 2019. Perilaku Remaja. semarang, n.d.

Sidjabat, B.s. Mengajar Secara Profesional. bandung, n.d.

Sriyati, Sriyati, and Esen Hon Nakamnanu.

"Peran Guru Dalam Menerapkan

Pendidikan Agama Kristen Untuk

Menumbuhkan Iman Kristen Anak

Sejak Dini.” SHAMAYIM: Jurnal

Teologi dan Pendidikan Kristiani 1, no. 1 (January 19, 2021): 14-28. http://www.sttybmanado.ac.id/ejournal/index.php/shamayim/article/vie
Commented [l1]: Tolong tidak dibuat seperti ini, bisa dideskrifsikan tanpa point2,, atau sbb: Pertama sabar....kedua disiplin...ketiga tidak memainkan emosi

remaja...dst 
w/2. 